\title{
Determining Soil Thermal Conductivity Through Numerical Simulation of a Heating Test on a Heat Exchanger Pile
}

\author{
K. L. Yu • R. M. Singh $\cdot$ A. Bouazza $\cdot$ H. H. Bui
}

Received: 3 January 2014 / Accepted: 27 February 2015/Published online: 7 March 2015

(C) Springer International Publishing Switzerland 2015

\begin{abstract}
Heat exchanger pile foundations have a great potential of providing space heating and cooling to built structures. This technology is a variant of vertical borehole heat exchangers. A heat exchanger pile has heat absorber pipes firmly attached to its reinforcement cage. Heat carrier fluid circulates inside the pipes to transfer heat energy between the piles and the surrounding ground. Borehole heat exchangers technology is well established but the heat exchanger pile technology is relatively new and requires further investigation of its heat transfer process. The heat transfer process that affects the thermal performance of a heat exchanger pile system is highly dependent on the thermal conductivity of the surrounding ground. This paper presents a numerical prediction of a thermal conductivity ground profile based on a field heating test conducted on a heat exchanger pile. The thermal conductivity determined from the numerical simulation was compared with the ones evaluated from field and laboratory experiments. It was found that the thermal conductivity quantified numerically was in close agreement with the laboratory test results, whereas it differed from the field experimental value.
\end{abstract}

K. L. Yu · A. Bouazza · H. H. Bui

Monash University, Melbourne, Victoria 3800, Australia

R. M. Singh ( $\square)$

University of Surrey, Guildford, GU2 7XH, UK

e-mail: r.singh@surrey.ac.uk
Keywords Heat exchanger pile $\cdot$ Heat absorber pipes - Heat transfer - Thermal conductivity · Thermal response test

\section{Introduction}

Geothermal pile foundations also known as heat exchanger piles or geothermal piles have been extensively used in Europe for the last decade as a form of shallow geothermal energy for heating and cooling of built structures (Brandl 2006; Laloui et al. 2006; Pahud and Hubbuch 2007; Quick et al. 2010; Boranyak 2013). Heat exchanger piles comprise high density polyethylene (HDPE) heat absorber pipes in which a heat carrier fluid circulates and promotes heat energy exchange between the built structure and the ground (Brandl 2006). In the past several years, an increasing number of studies of this technology have been reported by numerous researchers (Hamada et al. 2007; Gao et al. 2008; Bourne-Webb et al. 2009; Brettmann et al. 2010; Colls et al. 2012; Wang et al. 2013) indicating an increasing uptake in various countries across the world (DeMoel et al. 2010; Laloui and Di Donna 2011; Bouazza et al. 2011; Wang et al. 2014).

This technology is very beneficial for building developers and investors as it can serve not only as a structural support of the built structure, but also as an effective underground heat exchanger which can generate great savings in power bills at a low additional 
installation cost of the heat exchanging loops. This installation cost is dependent on the pile construction technique adopted for the project (i.e. bored piles, CFA piles, steel piles or others). Pahud and Hubbuch (2007) and Laloui and Di Donna (2011) indicated that the geothermal foundation system for Dock Midfield terminal at Zurich airport in Switzerland delivered a thermal energy cost of $€ 0.06 / \mathrm{kWh}$ compared with $€ 0.08 / \mathrm{kWh}$ for a conventional solution. The additional investment of the system at the airport was paid back in full in about 8 years. Initial installation costs are the largest expense for shallow geothermal energy systems, but these are expected to be reduced as these systems become more popular while the conventional energy costs are expected to increase, therefore, the investments could be paid back in a shorter period in the future (Johnston et al. 2011). This renewable, sustainable and environmental friendly technology is now increasingly drawing attention in Australia (Bouazza et al. 2011; Johnston et al. 2011). The implementation of geothermal pile foundation systems has a great potential in Australian cities such as Melbourne, due to its balanced seasonal climate throughout the year and its geology which requires deep foundations for buildings in many different areas of the city.

In order to accurately design a geothermal pile system, knowledge of the heat transfer process in the ground is required. Thermal conduction is the main heat transfer mechanism taking place in the ground (Brandl 2006). The amount or rate of heat transfer contributed by this mechanism is largely dependent on the thermal conductivity of the ground. The thermal conductivity is a very crucial parameter in the design of heat exchanger piles, because it is used to determine the amount of thermal energy that can be extracted from or injected into the ground.

This paper presents a numerical prediction of the thermal conductivity of a soil profile based on a heating test of a heat exchanger pile conducted by Wang et al. (2012, 2013). The test pile contained three absorber pipe loops; however, the results reported herein are for the case of one working loop only. The numerical predictions were compared with the laboratory tests conducted on the soil profile material reported by Barry-Macaulay et al. (2013) and the field data analysis conducted by Wang et al. (2013).

\section{Pile Test}

\subsection{Experimental Setup}

A heat exchanger pile and two boreholes were installed at Monash University Clayton campus by Wang et al. (2012, 2013, 2014). The bored pile is $16.1 \mathrm{~m}$ long and has a diameter of $0.6 \mathrm{~m}$. Two boreholes were installed such that their centres were located 0.5 and $2 \mathrm{~m}$ away from the edge of the test pile, respectively. Thermocouples were placed at $2 \mathrm{~m}$ intervals to the depths of 18 and $16 \mathrm{~m}$ for boreholes 1 and 2, respectively. Two Osterberg cells were installed at 10.1 and $14.4 \mathrm{~m}$ depths for the investigation of thermo-mechanical behaviour which is not discussed in this paper. Embedment strain gauges and sister bar fitted with thermistors were installed at 5.4, 6.4, 8.2, $11.6,12.5$ and $13.3 \mathrm{~m}$ depths in the test pile as shown in Fig. 1.

The ground temperature variation with depth was monitored regularly through an automated computer system. The heat absorber piping installed in the test pile consisted of three heat exchanging loops of high density polyethylene (HDPE) pipes. The loops have an outer diameter of $25 \mathrm{~mm}$ and an inner diameter of $20 \mathrm{~mm}$. They were attached to the pile reinforcement cage which had a length of $14.2 \mathrm{~m}$. Water was used as the heat carrier fluid inside the loops during the pile tests. The section of the tubing on the ground surface, connected to the thermal response test unit, was insulated by black foam and was covered by a layer of aluminium foil in order to reflect the sunlight and avoid solar radiation affecting the fluid temperature inside the loops.

\subsection{Ground Condition}

The shaft of the test pile was drilled in Brighton Group material which covers extensively the south-eastern area of Melbourne (Geological Survey of Victoria 1981). The Brighton Group material encountered at the test site is Red Bluff Sands, which consists of fine to coarse very dense clayey sands and sands. The geotechnical profile of the test site and the soil moisture content at various depths are presented in Table 1a, b, respectively. The undisturbed ground temperature ranges from 16 to $17.5{ }^{\circ} \mathrm{C}$ along the depth of $16 \mathrm{~m}$ (Wang et al. 2013). 




Fig. 1 Locations of thermocouples within borehole and embedment strain gauges and sister bar within test pile

\subsection{Heating Test Method}

A heating test was performed on the test pile by Wang et al. (2012), using a thermal response test (TRT) unit to determine the thermal conductivity of the ground for the geothermal pile system. The TRT unit consisted of a computerised logging system, control box, water pump, heating elements and a water reservoir. There was one inlet and one outlet on the TRT unit, a manifold was used to reduce the three inlets and three outlets of the pile loops down to only one for the connection with the TRT unit. Although the system could accommodate three loops, only one loop was connected and used in the test discussed in 
Table 1 (a) Geological stratigraphy of the test site (Wang et al. 2013), (b) soil moisture content at various depths (Wang et al. 2013)

\begin{tabular}{|c|c|c|c|}
\hline Depth (m) & Soil type & Sample or field test value & Consistency or density \\
\hline \multicolumn{4}{|l|}{ (a) } \\
\hline $0-1.5$ & Clayey fill & - & - \\
\hline $1.5-2.5$ & Sandy clay & $\mathrm{PP}>400 \mathrm{kPa}$ (pocket penetrometer test) & Hard \\
\hline $2.5-10$ & Sand with trace of clay & $\mathrm{N}=26$ at $3 \mathrm{~m}$ depth & Dense at $3 \mathrm{~m}$ depth \\
\hline & & $\mathrm{N}=\mathrm{HB}$ below $3 \mathrm{~m}$ depth (standard penetration test) & Very dense below $3 \mathrm{~m}$ depth \\
\hline $10-16.1$ & Sand & $\mathrm{N}=\mathrm{HB}$ (standard penetration test) & Very dense \\
\hline Depth (m) & & & Soil moisture content $(\%)$ \\
\hline \multicolumn{4}{|l|}{ (b) } \\
\hline 0.5 & & & 28.2 \\
\hline 1.5 & & & 19.3 \\
\hline 3.0 & & & 12.1 \\
\hline 4.0 & & & 8.5 \\
\hline 5.0 & & & 7.5 \\
\hline 6.0 & & & 6.5 \\
\hline 8.0 & & & 4.2 \\
\hline 10.0 & & & 4.9 \\
\hline 11.0 & & & 3.5 \\
\hline 12.5 & & & 2.8 \\
\hline 14.2 & & & 2.2 \\
\hline
\end{tabular}

$H B$ hammer bounce during standard penetration test $(\mathrm{N}>50)$

this study. During the test, the heat carrier fluid (water) was continuously circulated inside the loop while the inlet and outlet fluid temperatures and the ground temperature were continuously recorded. The average inlet/outlet fluid temperature increased as the constant heating power was applied by the heat pump to the fluid. The constant heating power applied was $2.4 \mathrm{~kW}$ which actually overheated the fluid. Consequently to avoid causing damage to the pipe loop, the test was aborted after 3 days of heating. Over these 3 days, the average fluid temperature (average of inlet and outlet) increased from 20 to $48{ }^{\circ} \mathrm{C}$ approximately. The fluid temperatures and ambient air temperature against time (in log scale) are shown in Fig. 2 as reported by Wang (2013).

Thermal conductivity is the ability of a material to transfer heat energy by conduction. Such ability is represented by the amount of heat energy transferred over a distance and time due to a temperature difference between two locations in a material. The thermal conductivity of the ground is calculated by interpreting the experimental data measured during a heating test. Wang (2013) initially analysed the experimental data based on the infinite line heat source method, in which a known and recorded energy is applied to the ground heat exchanger while the inlet and outlet fluid temperatures are also recorded. Infinite line heat source method assumes that the ground heat exchanger functions as a constant line heat source in an infinite region. The thermal conductivity calculated using this method is considered to be an effective value, as the method assumes a homogenous medium around the heat source and does not consider the variable ground and groundwater conditions. The effective thermal conductivity is calculated by the following:

$\lambda_{\text {eff }}=\frac{Q}{4 \pi K L_{b}}$

where $\mathrm{Q}$ is the constant input power of the heating elements in Watts (W), $\mathrm{L}_{\mathrm{b}}$ is the effective length of the ground heat exchanger in metre $(\mathrm{m}), \mathrm{K}$ is the slope of average fluid temperature against logarithmic of time. Since the infinite line heat source phenomenon (a thermal steady state achieved by the heat exchanger) only occurs after a sufficient length of heating time, the minimum time criterion has to be satisfied. This criterion relates to a mathematical 
Fig. 2 Average fluid and ambient air temperature versus logarithmic time



3 Numerical Modelling

simplification to the line source solution. Therefore, the initial test data collected prior to a thermal steady state is considered to be inapplicable and ignored (Kavanaugh et al. 2001). The amount of discarded test data (minimum time) was obtained by the following equation:

$t>\frac{5 r^{2}}{\alpha}$

where $r$ is the radius of the ground heat exchanger and $\alpha$ is the thermal diffusivity of soil.

It needs to be noted that the line source method was found to not be suitable for the interpretation of pile heating tests (Wang et al. 2013; Loveridge et al. 2014). This work highlights further its unsuitability to analyse pile heating tests.

The thermal diffusivity of soil was calculated from the measured borehole (ground) temperature during the heating test based on the dual-probe method introduced by Bristow et al. (1994). The soil thermal diffusivity for the 1-loop heating test was $1.16 \times 10^{-6} \mathrm{~m}^{2} / \mathrm{s}$ as reported by Wang (2013). With the diameter of the pile, $600 \mathrm{~mm}$ (300 mm radius), the minimum time was determined to be $108 \mathrm{~h}$ (4.5 days) using Eq. (2), which is longer than the actual duration of the test ( 3 days). Due to the early termination of the test, only data collected within the last $24 \mathrm{~h}$ of the test was considered in the calculation of the slope of fluid temperature against log time. The effective thermal conductivity for the test pile system at Clayton campus was $4.19 \mathrm{~W} / \mathrm{mK}$ using Eq. (1) (Wang et al. 2012). This thermal conductivity is considered to be inaccurate and the reasons for this are discussed in Sects. 5.2 and 5.3.

\subsection{Fundamentals of Heat Transfer}

A finite element method (FEM) modelling software, COMSOL multiphysics was used to capture the heat transfer process of the geothermal pile system during the thermal response tests. In this approach, the numerical model considers the geometry of the pile and the variable ground condition and groundwater condition (if any) and solves the heat transfer problem. Therefore, this approach should provide more accurate results than the infinite line heat source method.

Heat transfer in solids for a heat exchanger pile as a primary heat exchanger occurs in the surrounding ground, the pile material (concrete and/or steel) and the pipe wall. Thermal conduction is considered to be the governing heat transfer process in solids. Thermal conduction is the transfer of heat energy that occurs due to the interaction between the particles with a higher energy and a lower energy (Incropera and DeWitt 2002). The heat diffusion used in this mode of heat transfer process is written as

$\rho C_{p} \frac{\partial T}{\partial t}-\nabla \cdot(k \nabla T)=Q$.

The equation includes materials properties such as: the density $\rho$ in $\mathrm{kg} / \mathrm{m}^{3}$ ), the specific heat capacity $C_{p}$ in $\mathrm{J} /(\mathrm{kg} \mathrm{K})$, and the thermal conductivity $k$ in $\mathrm{W} /(\mathrm{mK})$ (a scalar or a tensor if the thermal conductivity is anisotropic), and a heat source (or sink) $Q$ in $\mathrm{W} / \mathrm{m}^{3}$. The term $\rho C_{p}$ is the effective volumetric heat capacity. The thermal conductivity describes the relationship between the heat flux vector $\mathrm{q}$ and the temperature 
gradient $\nabla \mathrm{T}$ as in Fourier's law of heat conduction $q=-k \nabla T$ (COMSOL 2010).

\subsection{Numerical Model Description}

The available test data is time dependent and includes the inlet and outlet fluid temperatures and ground temperatures measured in the two boreholes shown in Fig. 1. These sets of data were used in the numerical simulation. A two-dimensional FE model was developed for each of the $2 \mathrm{~m}$ depth intervals along the whole depth of borehole 1 ( $0.5 \mathrm{~m}$ away from the edge of the test pile), to simulate the heat flow in radial direction only as it is a 2D simulation of a horizontal cross-section. The 16 and $18 \mathrm{~m}$ depths were ignored as the base of the loops is at $14.1 \mathrm{~m}$ depth only, thus, seven 2D FE models were developed for 2, 4, 6, 8, 10, 12 and $14 \mathrm{~m}$ depths, respectively. The centre-to-centre spacing between the inlet and outlet pipes is $150 \mathrm{~mm}$. The ground temperature measured in borehole $2(2 \mathrm{~m}$ away from the edge of the test pile) remained almost constant during the tests, therefore, it was used as a fixed boundary condition at the circumference of the circle covered by $10 \mathrm{~m}$ radius with the centre of the test pile being the centre of the circle. The initial temperature condition for the whole model was set to be the initial undisturbed ground temperature measured before the test. The model geometry for each of the seven depths is considered to be the same and is described in Fig. 3a, b. The initial and fixed boundary conditions are presented in Table 2. The overall mesh size was selected to be extra fine (element size of $410 \mathrm{~mm}$ ) in each of the models, the meshes around the inlet and outlet pipes were set to be finer (element size of $1.5 \mathrm{~mm}$ ) as the pipes are relatively small (only $20 \mathrm{~mm}$ inner diameter) compared with the $600 \mathrm{~mm}$ pile diameter. The sensitivity of the results to element size was tested by comparing extra fine with extra coarse meshes. It was found that the difference in results was negligible $\left(<0.01{ }^{\circ} \mathrm{C}\right.$ difference in borehole 1 temperature results). The final meshing of the model is shown in Fig. 4a, b.

It was assumed that the relationship between the fluid temperatures and the length of the U-shaped loop was linear, in other words, the fluid temperature decreases linearly along the length of loop (from the inlet to the outlet of the loop). This assumption is based on the numerically simulated fluid temperature change along the lengths of loops in a heat exchanger pile reported by Gao et al. (2008). The vertical fluid temperature variation along a W-shaped loop with different flow rates reported by Gao et al. (2008) is presented in Fig. 5.

As indicated in Fig. 5, the decrease in fluid temperature approached a linear variation as the flow rate increased. The decrease did achieve linearity at the double flow rate. The reference flow rate used was $5.7 \mathrm{~L} / \mathrm{min}(0.3 \mathrm{~m} / \mathrm{s}$ flow velocity considering $20 \mathrm{~mm}$ inner diameter of pipe used by Gao et al. 2008), the half and double flow rates were $2.85(0.15 \mathrm{~m} / \mathrm{s})$ and $11.4 \mathrm{~L} / \mathrm{min}(0.6 \mathrm{~m} / \mathrm{s})$, respectively. Considering the small difference between the double flow rate of 11.4 $\mathrm{L} / \mathrm{min}(0.6 \mathrm{~m} / \mathrm{s})$ and the flow rate of $10.5 \mathrm{~L} / \mathrm{min}$ $(0.56 \mathrm{~m} / \mathrm{s}$ flow velocity in the same $20 \mathrm{~mm}$ inner diameter of pipe used in Wang et al. 2012), it can be deemed acceptable to assume that the fluid temperature decreased linearly in Wang et al. (2012)'s heating test.

Based on the assumption of linear decrease in fluid temperature along the loop, a set of time-dependent inlet and outlet fluid temperature data at every $2 \mathrm{~m}$ depth was established and imported into the numerical model as a boundary condition at the pipe boundaries, while the material of the domain inside the pipes was specified as water, with thermal conductivity of $0.6 \mathrm{~W} / \mathrm{mK}$ and heat capacity of $4180 \mathrm{~J} / \mathrm{kg} \mathrm{K}$ (COMSOL 2010). The measured ground temperature in borehole 1 was predicted numerically through a parametric analysis.

The thermal conductivities of the HDPE pipes and pile concrete used in the numerical models were 0.4 and $1.63 \mathrm{~W} / \mathrm{mK}$, respectively. These values were selected from available literature (INEOS Olefins and Polymers USA 2009; Gao et al. 2008; BarryMacaulay 2013). The thermal conductivity of the pile concrete was in the range of 1.28-1.91 W/mK (BarryMacaulay 2013) and was consistent with the values reported in literature. It should be noted that the selection of concrete thermal conductivity value is expected to influence the result of the numerical analysis as the thermal conductivities of concrete and ground are likely to be co-linear. The thermal conductivity of the reinforcement bars was $44.5 \mathrm{~W} /$ $\mathrm{mK}$ as specified in COMSOL built-in material properties (structural steel). 
Fig. 3 a Geometry of the numerical model. b Geometry of the numerical model (magnified view of the vicinity of the pile) (a)

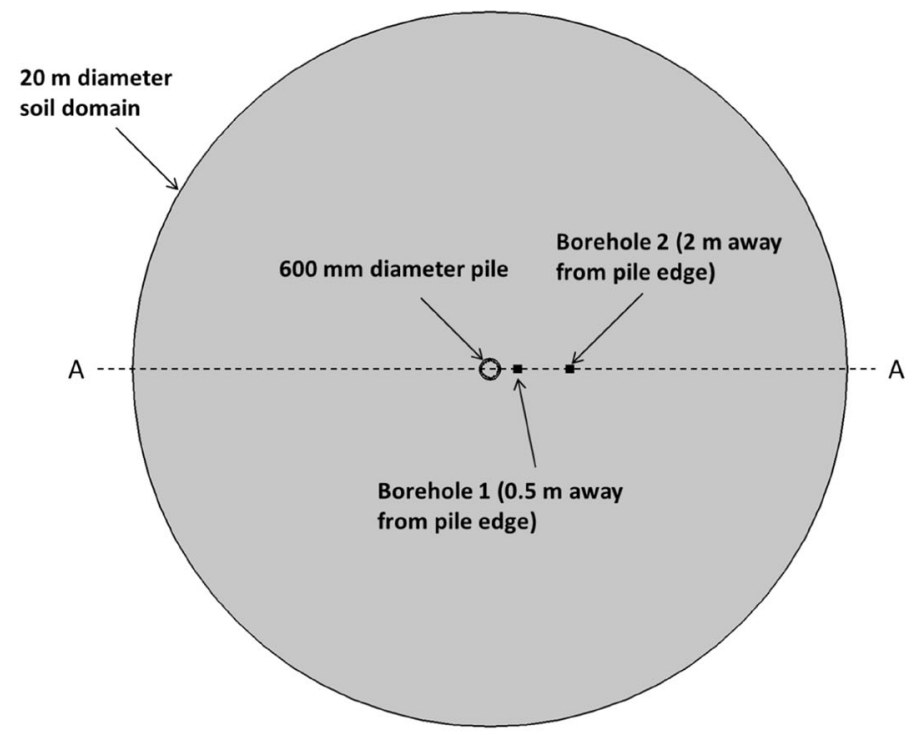

(b)



\section{Numerical Results}

\subsection{Heat Migration}

As the average fluid temperature (see Fig. 2) was kept higher than the initial undisturbed ground temperature $\left(16-17.3^{\circ} \mathrm{C}\right)$ at all times during the test except for the first several minutes, heat energy migrated, in radial direction in the case of a horizontal cross-section simulation, from the fluid to the pipe wall, then to the pile concrete and finally to the surrounding soil. A typical temperature distribution predicted by the numerical model at the end of the 3-day heating test is illustrated in Fig. 6. It is to be noted that heat did not migrate any further than approximately 1.8 and $1.4 \mathrm{~m}$ away from the right and left hand side of the pile along 
Table 2 Initial and fixed boundary conditions used in FEM simulation

\begin{tabular}{lll}
\hline $\begin{array}{l}\text { Pile } \\
\text { depth }(\mathrm{m})\end{array}$ & $\begin{array}{l}\text { Initial condition i.e. initial } \\
\text { undisturbed ground temperature } \\
\text { measured in borehole } 1\left({ }^{\circ} \mathrm{C}\right)\end{array}$ & $\begin{array}{l}\text { Fixed boundary condition i.e. } \\
\text { nearly constant ground temperature } \\
\text { measured in borehole } 2\left({ }^{\circ} \mathrm{C}\right)\end{array}$ \\
\hline 2 & 16.0 & 15.7 \\
4 & 16.3 & 16.2 \\
6 & 16.6 & 16.2 \\
8 & 16.4 & 16.2 \\
10 & 16.4 & 16.4 \\
12 & 17.0 & 17.2 \\
14 & 17.3 & 17.7 \\
\hline
\end{tabular}

Fig. 4 Meshing of numerical model with a overall, b magnified view of the pile


(a) Fluid temperature $\left({ }^{\circ} \mathrm{C}\right)$

$$
\begin{array}{lllllllll}
28 & 29 & 30 & 31 & 32 & 33 & 34 & 35 & 36
\end{array}
$$



(b)

Fluid temperature $\left({ }^{\circ} \mathrm{C}\right)$



(c)

Fluid temperature $\left({ }^{\circ} \mathrm{C}\right)$



Fig. 5 Vertical fluid temperature variation along a W-shaped loop with a half flow rate, $\mathbf{b}$ reference flow rate, $\mathbf{c}$ double flow rate (modified from Gao et al. 2008)

Section A-A in Fig. 3a. A typical example of ground temperature variation along the radial distance from the pile edge ( $8 \mathrm{~m}$ depth) is shown in Fig. 7.

The heat migration from the heated pile (heat source) into the ground was caused by the temperature difference between the pile and the surrounding ground temperature. The potential of the heat migration at a location closer to the heat source is higher than a location farther away from it, due to the accumulated loss of heat energy from the source to the surrounding soil as the heat migrates further into the soil. This explains why the ground temperature curves became flatter with the increase in the radial distance from the pile edge as observed in Fig. 7. 
Fig. 6 Typical temperature distribution in the crosssection of the numerical model

\subsection{Thermal Conductivity}

The thermal conductivity was evaluated by conducting a parametric study varying the thermal conductivity until the numerical and field experimental results were close to each other. The thermal conductivity for each depth was calibrated while considering the values reported by Barry-Macaulay (2013) and Wang (2013). The outcome of this parametric analysis is shown in Fig. 8. The largest difference between numerical and field experimental results is merely $0.3{ }^{\circ} \mathrm{C}$ within all data. Moreover, both trends of ground temperatures variation with time are very similar to each other.

The ground temperatures at $2 \mathrm{~m}$ individual depths representing the initial and fixed boundary conditions as shown in Table 2 were then averaged $\left(16.6{ }^{\circ} \mathrm{C}\right.$ in both boreholes 1 and 2). Together with the averaged inlet and outlet fluid temperatures considering all individual depths, the 'average' scenario was obtained by the same parametric analysis and is presented in Fig. 9. The largest difference between numerical and experimental results for this average scenario is $0.2{ }^{\circ} \mathrm{C}$ and the trend of the temperature increase is very similar to the trend shown in Fig. 8. The thermal conductivity used in the numerical simulation for this average is $1.8 \mathrm{~W} / \mathrm{mK}$.
The thermal conductivities at the various depths corresponding to the numerical results were compared with the laboratory test results by Barry-Macaulay (2013) as presented in Table 3, based on the soil moisture contents and densities discussed in Sect. 5.1.

\section{Thermal Conductivity Results Discussions}

\subsection{Soil Moisture Content and Density}

The range of thermal conductivities determined from the numerical simulation is comparable with that determined from the laboratory tests performed by Barry-Macaulay et al. (2013). The selected laboratory test results presented in Fig. 10a, b showed that the thermal conductivities of both Brighton Group clayey sand and Brighton Group sand increased with the increase in soil moisture content and density. The thermal conductivity of Brighton Group materials was measured with the use of thermal needle probe (KD2 Pro thermal properties analyser). The thermal needle probe method is also based on the infinite line heat source theory. The needle probe had a length of $60 \mathrm{~mm}$ and a diameter of $1.27 \mathrm{~mm}$. The method calculates the thermal conductivity by monitoring the thermal 
Fig. 7 a Ground temperature versus radial distance from pile edge (on the right hand side along Section A-A in Fig. 3a) at different times during heating test at $8 \mathrm{~m}$ depth based on numerical simulation. b Ground temperature versus radial distance from pile edge (on the left hand side along Section A-A in Fig. 3a) at different times during heating test at $8 \mathrm{~m}$ depth based on numerical simulation

Fig. 8 Experimental and numerical results of ground temperature at borehole 1 over the duration of single U-loop test (a)

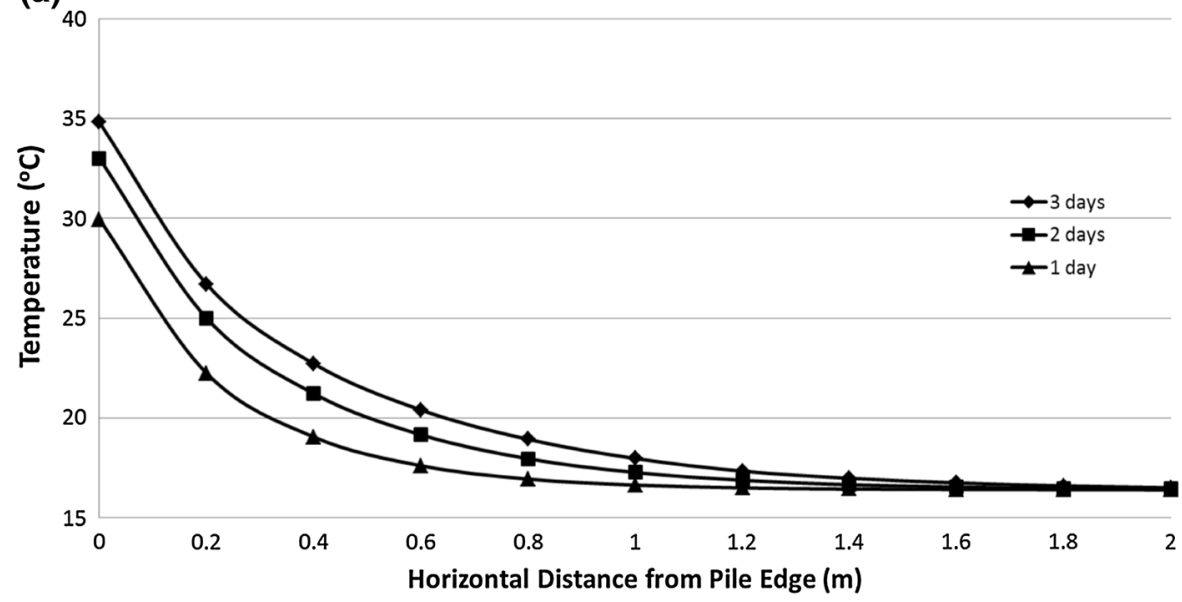

(b)

Fig. 9 Experimental and numerical results of average ground temperature at borehole 1 over the duration of single U-loop test



Table 3 Thermal conductivity results from laboratory tests and numerical modelling, according to ground profile

\begin{tabular}{|c|c|c|c|c|c|}
\hline $\begin{array}{l}\text { Depth } \\
\text { (m) }\end{array}$ & Soil type & $\begin{array}{l}\text { Dry density } \\
\left(\mathrm{kg} / \mathrm{m}^{3}\right) \text { from } \\
\text { Chandler }(1992)\end{array}$ & $\begin{array}{l}\text { Moisture } \\
\text { content }(\%)\end{array}$ & $\begin{array}{l}\text { Laboratory thermal } \\
\text { conductivity result } \\
\text { (Barry-Macaulay 2013) } \\
(\mathrm{W} / \mathrm{mK})\end{array}$ & $\begin{array}{l}\text { Thermal conductivity } \\
\text { estimated by } \\
\text { numerical models } \\
(\mathrm{W} / \mathrm{mK})\end{array}$ \\
\hline 2 & Brighton group clayey sands & 1400 & $12.1-19.3$ (selected 16) & 1.5 & 1.3 \\
\hline 4 & Brighton group clayey sands & $1750-1950$ & 8.5 & $1.8-2.2$ & 1.8 \\
\hline 6 & Brighton group clayey sands & $1750-1950$ & 6.5 & $1.5-2$ & 1.8 \\
\hline 8 & Brighton group clayey sands & $1750-1950$ & 4.2 & $1.3-1.7$ & 1.8 \\
\hline 10 & Brighton group sands & $1750-1950$ & 4.9 & $2-2.4$ & 1.5 \\
\hline 12 & Brighton group sands & $1750-1950$ & $2.8-3.5($ selected 3$)$ & $1.5-1.9$ & 2 \\
\hline 14 & Brighton group sands & $1750-1950$ & $2.2-2.8($ selected 2.5$)$ & $1.5-1.9$ & 1.2 \\
\hline
\end{tabular}

Fig. 10 Thermal conductivity versus dry soil density at various moisture contents for a Brighton group clayey sands and b Brighton group sands (after Barry-Macaulay et al. 2013)
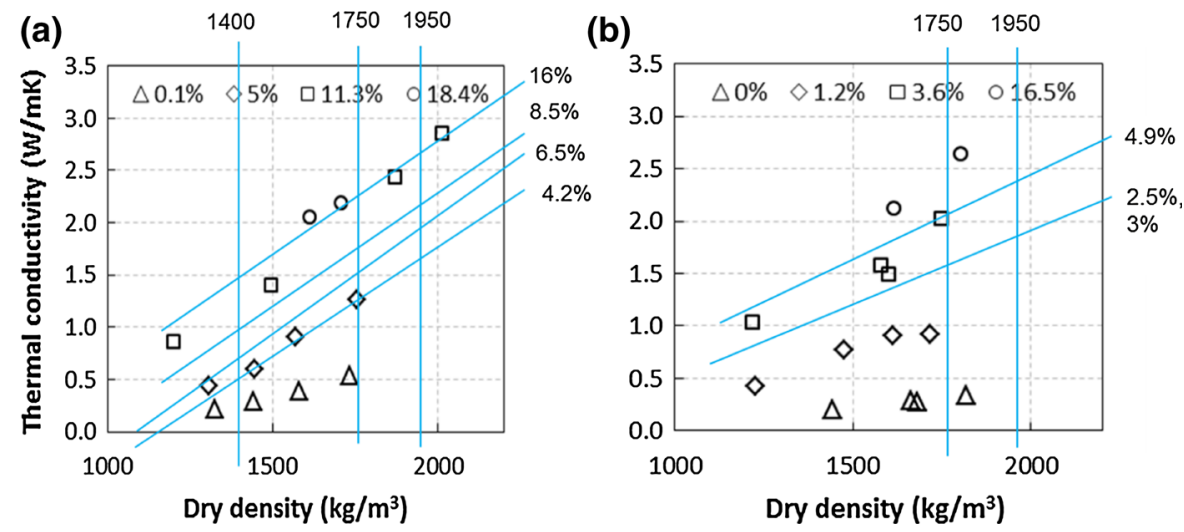

dissipation from the needle probe. The soil samples were disturbed and collected during the drilling of the pile shaft. Samples at various dry densities and moisture contents were prepared by static compaction. The small size of the needle probe and absence of concrete in the surrounding cause minimum uncertainties over the minimum time required for the occurrence of a thermal steady state and the colinearity of thermal conductivities. Therefore, the infinite line source theory used in the laboratory needle probe tests is expected to be valid.

The laboratory tested Brighton Group materials as shown above were from the excavated shaft of the test pile during the pile installation. The measured thermal 
conductivity of these materials ranged from 0.2 to $2.4 \mathrm{~W} / \mathrm{mK}$ as indicated in Fig. 10a, b.

According to Chandler (1992), the ranges of dry density for clayey and sandy Brighton Group materials are $1260-1480$ and $1530-1950 \mathrm{~kg} / \mathrm{m}^{3}$, respectively. From the numerical results, the thermal conductivity at $2 \mathrm{~m}$ depth is $1.3 \mathrm{~W} / \mathrm{mK}$ (Table 3). The soil at that depth is Brighton Group clayey sand, which has a dry density between 1260 and $1480 \mathrm{~kg} / \mathrm{m}^{3}$. Considering the hard soil strength encountered at this depth, the dry density of such soil should be within the higher end of the range, approximately $1350-1450 \mathrm{~kg} / \mathrm{m}^{3}$, say $1400 \mathrm{~kg} / \mathrm{m}^{3}$. The Brighton Group materials encountered at depths $4-14 \mathrm{~m}$ is very dense sand as presented in Sect. 2.2. The dry density of this material should be between 1750 and $1950 \mathrm{~kg} / \mathrm{m}^{3}$ according to Chandler (1992). Applying the values of dry density and moisture content for depths 2-8 m (Brighton Group clayey sands) to Fig. 10a, the laboratory result of thermal conductivity was estimated to be in an approximate range of $1.3-2.2 \mathrm{~W} / \mathrm{mK}$, which is in a close agreement with the numerical thermal conductivity values for depths $2-8 \mathrm{~m}, 1.3-1.8 \mathrm{~W} / \mathrm{mK}$, as presented in Table 3. However, for depths 10-14 m (Brighton Group sands), applying the values of dry density and moisture content in Table 3 to Fig. 10b, the corresponding laboratory results of thermal conductivity ranges between 1.5 and $2.4 \mathrm{~W} / \mathrm{mK}$, which is slightly higher than the numerical values $(1.2-2 \mathrm{~W} /$ $\mathrm{mK})$. The numerical thermal conductivity at 10 and $14 \mathrm{~m}$ depths are lower than the laboratory results. This is because a load cell (Osterberg cell) was installed at $10 \mathrm{~m}$ for the purpose of investigating the thermomechanical pile behaviour which is not discussed in this paper. The presence of load cell caused a discontinuity in the pile that affected the heat transfer from the pipe/pile to the surrounding soils. The $14 \mathrm{~m}$ depth is affected by boundary effects because the heat loops were installed down to a depth of $14.2 \mathrm{~m}$ (the bottom of the pile reinforcement cage), as a result, heat transfer at this depth takes place in both radial and vertical directions.

\subsection{Limitations of Infinite Line Source Method}

The infinite line source method adopted in the heating test analysis by Wang (2013) had its limitations on evaluating the thermal conductivity. The major limitation was caused by the insufficient duration of the heating test. The minimum time criterion was not satisfied as the test was aborted due to concerns over the overheated fluid damaging the pipe loop. The test pile did not achieve a thermal steady state when the test was aborted. The log-linear approach was invalid when the test data corresponding to the last $24 \mathrm{~h}$ of test was used to determine the thermal conductivity. Moreover, the inlet and outlet pipes were not centralised in the test pile which caused the heat source to be applied unsymmetrically in the pile. The accuracy of the result is considered to be sensitive to the axis symmetry considering the short duration of heating. Another factor which affected the thermal conductivity result of the infinite line source method is the short finite length of the pile $(16 \mathrm{~m})$. Philippe et al. (2009) reported that the additional effect of finite length considered in the finite line source method has significant influence on the time-dependent temperature at different radial distances for shallow borehole heat exchangers, while comparing with the temperature results obtained by the infinite line source method. This is because the heat transfer in vertical direction at the top and bottom of the borehole becomes significant for shallow boreholes, whereas the infinite line source method assumes the heat flow in radial direction only. It is expected that a similar phenomenon would have occurred in the event of the pile heating test mentioned in this study. It should also be recognised that the $2 \mathrm{D}$ numerical models in this study are likely to suffer the same limitation regarding finite length as the infinite line source method does.

\subsection{Other Limitations}

The determination of thermal conductivity might have been affected by ambient air temperature variations during the heating test. Austin (1998), Gehlin and Nordell (2003) and Bandos et al. (2011) reported the effect of daily atmospheric temperature variations on the measured fluid temperature. In this study, the difference between the fluid and air temperatures is shown in Fig. 2. The fluid temperature (both inlet and outlet) was measured approximately $15 \mathrm{~m}$ away from the pile top and the above-ground pipe section was 'insulated' by a thick black insulating foam and a layer of aluminium foil. However, it is difficult to entirely insulate the pipe section and the heat carrier fluid may gain or lose heat from or to the atmosphere subject to the air temperature (Bandos et al. 2011). The borehole 
heat exchanger test performed by Bandos et al. (2011) showed that the air temperature variations can distort the evaluation of the ground thermal conductivity by a factor of one-third (ranging from 2.6 to $3.5 \mathrm{~W} / \mathrm{mK}$ approximately in that particular test), whereas this kind of distortion for the geothermal pile applications has rarely been quantified and reported. Both methods to evaluate the ground thermal conductivity, for instance, the field test data interpretation approach and numerical modelling, are based on the measured fluid temperature. Therefore, it is expected that the accuracy of both results to be limited by the effect of ambient air temperature variations. While such an effect could hardly be eliminated, it could be captured by placing additional fluid temperature measuring gauges close to the pile top.

On the other hand, the concrete thermal conductivity was 1.28 (dry) and $1.91 \mathrm{~W} / \mathrm{mK}$ (wet), using the thermal needle probe method. A constant value of $1.63 \mathrm{~W} / \mathrm{mK}$ was selected for the numerical model. Considering the uncertain concrete moisture content during the pile heating, the concrete thermal conductivity was likely to vary with time between the dry and wet values and it was impossible to obtain the actual relationship between the conductivity and time. Therefore, the uncertainty over the concrete thermal conductivity is another potential limitation of the numerical model.

\section{Conclusions}

A numerical simulation of a single U-loop heating test was performed by developing a two dimensional numerical model for each of the $2 \mathrm{~m}$ depth intervals along the pile depth. Through the numerical simulation, the thermal conductivities of the soil at different depths were determined by matching the numerical and experimental results from the heating test. The determined thermal conductivities were also compared with the results from the laboratory tests on the soil samples which were collected from the excavated shaft of the test pile. It was found that the numerical results of thermal conductivities had close agreement with the laboratory test results, based on the soil moisture content and dry density. There was a significant difference between the numerical thermal conductivities and the effective thermal conductivity determined from the heating test results. This difference was due to the short duration of the heating test performed, the pipe loop not being centralised in the pile and the inadequacy of the infinite line source method as reported by Wang et al. (2012) became inapplicable in the evaluation of thermal conductivity of the ground. Moreover, it should be stressed that the accuracy of both numerical and experimental results is limited by the inevitable effect of air temperature variations on the measured fluid temperature. This effect on borehole heat exchangers has been quantified and reported by previous studies while its effect on heat exchanger piles has rarely been studied. However, the effect could be captured by obtaining additional fluid temperature measurement close to the pile top.

\section{References}

Austin WA (1998) Development of an in situ system for measuring ground thermal properties. MS thesis, Oklahoma State University, Stillwater, Oklahoma

Bandos TV, Montero A, de Cordoba PF, Urchueguia JF (2011) Improving parameter estimates obtained from thermal response tests: effect of ambient air temperature variations. Geothermics 40:136-143

Barry-Macaulay D (2013) An investigation on the thermal and thermo-mechanical behaviour of soils. MEngSc thesis, Monash University, Melbourne, Australia

Barry-Macaulay D, Bouazza A, Singh RM, Wang B, Ranjith PG (2013) Thermal conductivity of soils and rocks from the Melbourne (Australia) region. Eng Geol 164:131-138

Boranyak S (2013) International cooperation expands energy foundation technology. Deep Foundations Magazine, March/April edition, 51-65

Bouazza A, Singh RM, Wang B, Barry-Macaulay D, Haberfield C, Chapman G, Baycan S, Carden Y (2011) Harnessing on site renewable energy through pile foundations. Aust Geomech J 46(4):79-89

Bourne-Webb PJ, Amatya B, Soga K, Amis T, Davidson C, Payne P (2009) Energy pile test at Lambeth College, London: geotechnical and thermodynamic aspects of pile response to heat cycles. Geotechnique 59(3):237-248

Brandl H (2006) Energy foundations and other thermo-active ground structures. Geotechnique 56(2):81-122

Brettmann T, Amis T, Kapps M (2010) Thermal conductivity analysis of geothermal energy piles. In: Proceedings of the geotechnical challenges in urban regeneration conference, London, UK, pp 26-28

Bristow KL, White RD, Kluitenberg GJ (1994) Comparison of single and dual probes for measuring soil thermal properties with transient heating. Aust J Soil Res 32:447-464

Chandler KR (1992) Brighton Group-engineering properties. Eng Geol Melb 1992:197-203 
Colls S, Johnston I, Narsillo G (2012) Experimental study of ground energy systems in Melbourne, Australia. Aust Geomech 47(4):15-20

COMSOL (2010) Multiphysics reference guide. Stockholm, Sweden

DeMoel M, Bach PM, Bouazza A, Singh RM, Sun JO (2010) Technological advances and applications of geothermal energy pile foundations and their feasibility in Australia. Renew Sustain Energy Rev 14:2683-2696

Gao J, Zhang X, Liu J, Li K, Yang J (2008) Numerical and experimental assessment of thermal performance of vertical energy piles: an application. Appl Energy 85:901-910

Gehlin S, Nordell B (2003) Determining undisturbed ground temperature for thermal response test. Am Soc Heat Refrig Am Eng Trans 107:151-156

Geological Survey of Victoria (1981) Ringwood Geological Map. No. 809 Zone 7

Hamada Y, Saitoh H, Nakamura M, Kubota H, Ochifuji K (2007) Field performance of an energy pile system for space heating. Energy Build 39:517-524

Incropera F, DeWitt D (2002) Introduction to heat transfer, 4th edn. Wiley, New York

INEOS Olefins and Polymers USA (2009) Typical engineering properties of high density polyethylene. Technical data sheet. http://www.ineos.com/Global/Olefins\%20and\%20Polymers $\%$ 20USA/Products/Technical\%20information/INEOS\% 20Typical\%20Engineering\%20Properties $\% 20$ of $\% 20$ HDPE. pdf

Johnston IW, Narsillo GA, Colls S (2011) Emerging geothermal energy technologies. KSCE J Civil Eng 15(4):643-653

Kavanaugh SP, Xie L, Martin C (2001) Investigation of methods for determining soil and rock formation thermal properties from short-term field tests, ASHRAE 1118-TRP. American Society of Heating, Refrigerating and Air-Conditioning Engineers Inc

Laloui L, Di Donna A (2011) Understanding the behaviour of energy geo-structures. In: Proceedings of ICE 184-191
Laloui L, Nuth M, Vulliet L (2006) Experimental and numerical investigations of the behaviour of a heat exchanger pile. Int J Numer Anal Methods Geomech 30:763-781

Loveridge F, Brettmann T, Olgun CG, William P (2014) Assessing the applicability of thermal response testing to energy piles. In: Proceedings global perspectives on the sustainable execution of foundation works, Stockholm, Sweden, 21-23 May 2014

Pahud D, Hubbuch M (2007) Measured thermal performances of the energy pile system of the Dock Midfield at Zurich Airport. In: Proceedings European geothermal congress. Unterhaching, Germany

Philippe M, Bernier M, Marchio D (2009) Validity ranges of three analytical solutions to heat transfer in the vicinity of single boreholes. Geothermics 38:407-413

Quick H, Michael J, Huber H, Arslan U (2010) History of international geothermal power plants and geothermal projects in Germany. In: Proceedings world geothermal congress. Bali, Indonesia

Wang B (2013) Thermo-mechanical behaviour of geothermal energy piles. MEngSc, Monash University, Melbourne, Australia

Wang B, Bouazza A, Macaulay DB, Singh RM, Haberfield C, Chapman G, Baycan S (2012) Geothermal energy pile subjected to thermo-mechanical loading. In: Proceedings ANZ geomechanics regional conference, pp 626-631

Wang B, Bouazza A, Singh RM, Barry-Macaulay D, Haberfield C, Chapman G, Baycan S (2013) Field investigation of a geothermal energy pile: initial observations, In: Proceedings of the 18th international conference on soil mechanics and geotechnical engineering. Paris, France, pp 3415-3418

Wang B, Bouazza A, Singh M, Haberfield C, Barry-Macaulay D, Baycan S (2014) Post-temperature effects on shaft capacity of a full scale geothermal energy pile. J Geotech Geoenviron Eng. doi:10.1061/(ASCE)GT.1943-5606. 0001266 